OPEN ACCESS

Edited by:

Osama O. Zaidat,

Northeast Ohio Medical University,

United States

Reviewed by:

Alberto Maud

Texas Tech University Health Sciences

Center El Paso, United States

Saif Bushnaq,

St. Vincent Mercy Medical Center,

United States

*Correspondence:

Santiago Ortega-Gutierrez

santy-ortega@uiowa.edu

Specialty section:

This article was submitted to

Endovascular and Interventional

Neurology,

a section of the journal

Frontiers in Neurology

Received: 12 June 2020

Accepted: 11 August 2020

Published: 17 September 2020

Citation:

Guerrero WR, Dandapat $S$ and

Ortega-Gutierrez S (2020)

Hemorrhagic Cerebrovascular Pathology in the Pediatric Population.

Front. Neurol. 11:1055

doi: 10.3389/fneur.2020.01055

\section{Hemorrhagic Cerebrovascular Pathology in the Pediatric Population}

\author{
Waldo R. Guerrero ${ }^{1}$, Sudeepta Dandapat ${ }^{2}$ and Santiago Ortega-Gutierrez ${ }^{2 *}$ \\ ${ }^{1}$ Department of Neurosurgery, University of South Florida Morsani College of Medicine, Tampa, FL, United States, \\ ${ }^{2}$ Department of Neurology, Radiology, and Neurosurgery, University of lowa Carver College of Medicine, Comprehensive \\ Stroke Center, lowa City, IA, United States
}

Hemorrhagic cerebrovascular disease in the pediatric population can have devastating and long-term effects. Progress in the fields of genetics, neuroimaging, pharmacology, and surgical techniques has led to improved diagnosis and management of pediatric cerebrovascular diseases. In this review we discuss the current etiologies and medical and surgical treatments of hemorrhagic cerebrovascular pathology affecting infants and children. A special emphasis is placed on neuroendovascular treatment options. Increased knowledge about this unique pathology and the medical and therapeutic options will empower practitioners to more quickly and accurately identify and accurately treat hemorrhagic diseases in the pediatric population.

\footnotetext{
Keywords: cavernous malformation, developmental venous anomaly (DVA), aneurysm, arteriovenous malformations, pediatric
}

\section{PEDIATRIC HEMORRHAGIC CEREBROVASCULAR DISEASE IN INFANTS AND CHILDREN}

The incidences of non-traumatic subarachnoid hemorrhage (SAH) and intracerebral hemorrhage (ICH) in pediatric patients are 0.4/100,000/year and 0.8/100,000/year (1). Most cases of SAH and $\mathrm{ICH}$ in the pediatric population are a result of a secondary pathology such as a hematological condition, tumor, ruptured vascular malformation, or cerebral infection [Table 1; $(2,3)$ ]. In this section we will focus on the most common non-traumatic vascular causes. Of note vascular malformations might account for $17.5-73.5 \%$ of pediatric ICH [Table 1; (4-6)].

\section{SECTION 1: ARTERIOVENOUS MALFORMATIONS (AVMs)}

The presence of arteriovenous (AV) shunting through a nidus of coiled tortuous vascular connections that lack of capillaries and connect feeding arteries to draining veins are the hallmark of arteriovenous malformations (AVMs) (7). AVM incidence is estimated to be 1 per 100,000 per year (8). Although AVM incidence is lower in kids, they tend to rupture more frequently than in the adult population (9-13) and are the most frequent cause of ICH in the pediatric population (14). Although the exact pathophysiology remains to be elucidated, it is thought that the majority of AVMs develop during the 3rd week of embryogenesis secondary to persistence of development of a new AV connection form a presumed spontaneous mutation. AVMs have also been associated with specific genetic syndromes Table 2. However, mutations in RASA-1 have been associated with AVMs in a small number of families (15).

AVMs are usually diagnosed after ruptured with identification of a hematoma on a CT. MRI and $\mathrm{MR} / \mathrm{CT}$ angiography are the imaging modalities used to characterize the precise location and the therapeutic planning. DSA remains the gold standard to define the AVM architecture and assessing 
high risk features such as aneurysm and or venous stenosis or ectasias (16). It is important to recognize that DSA catheter angiogram might miss some components or even the entire AVM when performed in the acute setting of hemorrhage due to the compression of the AVM nidus by the hematoma (17).

AVMs have an annual hemorrhage rate that is thought to be between 2 and $4 \%$ with a mortality up to $25 \%$ per each event (14). This risk is elevated during the first 5 years postdiagnosis (18-20). The risk of rupture or re-rupture is also higher in the presence of high-risk features such as infratentorial or deep-seated AVMs, deep venous drainage, female sex, associated aneurysms and diffuse AVM morphology (21-26). Given the longer presumed life expectancy and higher risk, conservative management is largely abandoned, despite the natural history not being fully understood in this population. The risk or rupture or re-bleeding persist until the AVM is completely obliterated (27-29), thus the ultimate goal of treatment is to obtain complete angiographic abolition of the AVM with

Abbreviations: ICH, intracerebral hemorrhage; SAH, subarachnoid hemorrhage; AVM, arteriovenous malformations; AV, arteriovenous; AVFs, arteriovenous fistulas; CM, cavernous malformations; DVA, developmental venous anomaly.

TABLE 1 | Most common etiologies of spontaneous intracerebral hemorrhage in children.

Vascular malformations (50\%)
Arteriovenous malformations (39\%)
Cavernous malformations (11\%)
Bleeding diathesis (21\%)
Coagulopathies: liver failure, DIC, congenital
Thrombocytopenias: malignant (ALL, AML), congenital (aplastic anemia,
bone marrow failure), immune mediated, autoimmune
Aneurysm (9\%)
Hemorrhagic primary intracranial tumor (6\%)
Other (10\%)
Hemorrhagic CNS infection
Cerebral vasculitis
Moyamoya disease
Illicit drug abuse

none or minimal neurological sequelae. Treatment options include embolization, stereotactic radiosurgery, and surgical resection. Often a combination treatment is needed. Because of this, the decision to treat pediatric AVMs must include a multidisciplinary team with a neurointerventionalist with expertise in pediatric, a vascular surgeon with expertise in pediatrics, and a radiation oncologist. Although data in this population is still lacking, surgical resection remains the gold standard when feasible and safe (30). It has the potential of offering immediate cure as a single modality or in combination, while also providing evacuation of the hematoma in the acute settings. Various cases series reports obliteration rates between 67 and 100\% for children presenting with Spetzler-Martin grades $1-3$, with a mortality and morbidity of $\sim 5 \%$ respectively. Embolization results are modest when used as a single modality with obliteration rates up to $21 \%$ and complication rates up to $7 \%$ when performed in high volume centers [Figure 1; $(31,32)]$. However, embolization is usually utilized as an adjunct treatment option to resection to decrease the risk perioperative hemorrhage. Resection is usually done within $24-48 \mathrm{~h}$ from embolization thus reducing the risk of intraparenchymal hemorrhage that can occur from rapid rerouting of blood flow from a (now resected) low-resistance AVM into higher resistance normal vasculature (unused to handling the high flow previously running through the AVM), the so-called "normal perfusion breakthrough syndrome" (33). Only a few studies have demonstrated the efficacy and safety profile of radiosurgery as a single modality, achieving obliteration rates between 43 and $80 \%$ with neurological complications around $4 \%$ (29, 34). Higher-grade lesions carry a lower chance of successful treatment with all modalities but in reference to radiosurgery the rate of successful treatment is $(\approx 35 \%)$ (35). However, before its standard application, long term follow-up is required to understand the effects of ionizing radiation on the developing nervous system and the incidence of intracranial malignancies and neuropsychological retardation in children $(36,37)$. In all cases of treatment, long-term evaluation is critical because recurrence rates can be as elevated as $11 \%(38,39)$. Usually a perioperative and 1-year post-operative DSA are done. This is surveillanced by MRI/MRA annually for the subsequent 5 years $(33,39,40)$.

TABLE 2 | AVM-associated syndrome genetics.

\begin{tabular}{|c|c|c|c|c|}
\hline Syndrome & Mutated gene & Gene product & $\begin{array}{l}\text { Molecular mechanism for } \\
\text { AVM formation }\end{array}$ & Mode of inheritance \\
\hline \multicolumn{5}{|l|}{$\begin{array}{l}\text { Hereditary hemorrhagic telangiectasia } \\
(\mathrm{HHT})\end{array}$} \\
\hline $\mathrm{HHT1}$ & ENG & & & Autosomal dominant \\
\hline HHT2 & ACVRL/ALK1 & & & \\
\hline Juvenile polyposis-HHT overlap & SMAD4 & & & \\
\hline Parkes-Weber's syndrome & RASA1 & RAS p21 protein activator & $\begin{array}{l}\text { Abnormal angiogenic remodeling } \\
\text { of primary capillary plexus }\end{array}$ & Autosomal dominant/sporadic \\
\hline Wyburn-Mason's syndrome & NA & NA & Unknown & Sporadic \\
\hline
\end{tabular}




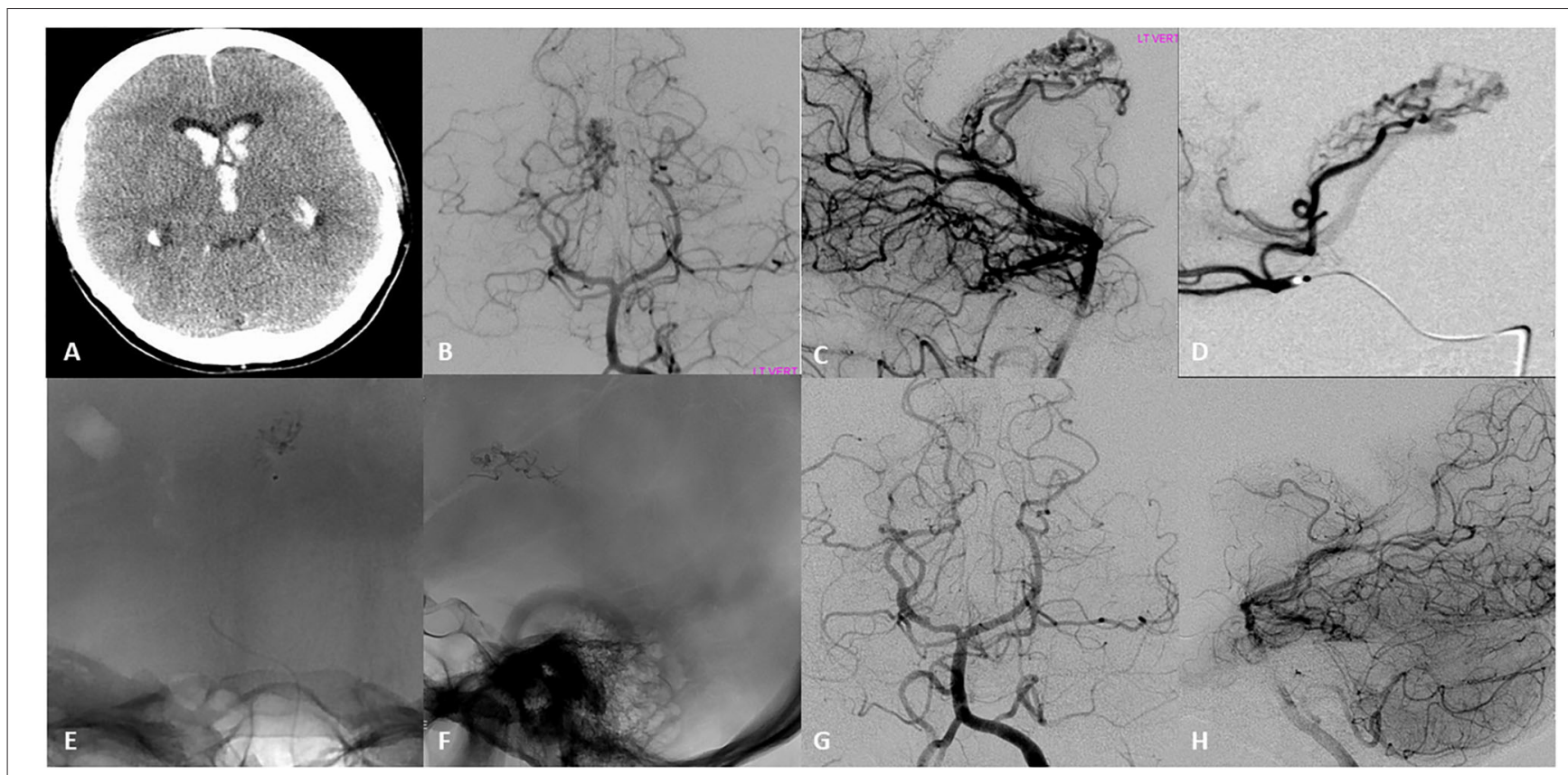

FIGURE 1 | Seventeen-year-old right-handed healthy girl that presented with initial headache nausea and vomiting, that progress to decrease level of consciousness within hours. (A) Initial head CT revealed intraventricular hemorrhage in the lateral ventricles and third ventricle, for which she underwent emergent ventriculostomy. (B,C) Initial DSA AP and lateral left vertebral artery injection revealed an arteriovenous malformation with a compact nidus located in the lateral ventricle. Arterial feeders arise from the post-erolateral and post-eromedial choroidal arteries, both branches of the right posterior cerebral artery. The drainage occurred into the right internal cerebral vein. (D) Superselective DSA examination showed a medial posterior choroidal artery that appeared to feed the nidus of the AVM with opacification of the right internal cerebral vein. (E,F) AP and Lateral native images demonstrate the N-Butyl cyanoacrylate (NBCA) cast into the nidus after microcatheter embolization of two pedicles. $(\mathbf{G}, \mathbf{H})$ DSA Ap and lateral 6-month follow up showed with complete obliteration of the AVM.

\section{SECTION 2: ARTERIOVENOUS FISTULAS (AVFs)}

Arteriovenous fistulas (AVFs) are direct arterial to venous connections deprived of intervening capillaries. Unlike AVMs, AVFs do not contain nidus. Two groups of AVFs exist based on the location of the arterial-venous connection: pial and dural. AVFs can be acquired or congenital. The specific genetic patterns of these lesions are still not wellunderstood; however, numerous molecules have been implicated in the pathogenesis including vascular endothelial growth factor, sonic hedgehog, upstream-transcription factor II, notch chicken ovalbumin, and the ephrin family. Congenital pial AVFs have been linked to various congenital diseases, the commonest of which is hemorrhagic hereditary telangiectasia which co-presents with AVFs in one-quarter of patients (41). Recent data suggest that $\approx 9 \%$ of patients with AVFs will harbor known mutations (41-43). RASA-1- and HHTrelated mutations (ENG and ACVRL1) were most commonly associated with clinical phenotypes including cranial lesions, hypercoagulable state, spinal AVF/AVM, capillary hemangioma (in RASA-1) (15, 41-43).

AVFs can also be acquired. Sinus hypertension and sinus thrombosis have been implicated in the development of dual AVFs (44). Dural AVFs have been seen in patients with hypercoagulable states leading to sinus thrombosis (45). Furthermore, trauma has been shown to be associated with AVFs.

The estimated prevalence of pial AVFs ranges between $0.1 / 100,0000$ and 1/100,000 (46-49) accounting for $\sim 4 \%$ of cerebral vascular malformations in the pediatric population ( 31 , 49) and normally presenting between that ages of 3-15 years of age (31). Dural AVFs are more common in adults and its prevalence is not well-studied in the pediatric population. AVFs have a high risk of hemorrhage secondary to high flow (50), with a reported risk of hemorrhage of 1.5-10\% annually depending on particular factors such as fistulas at the vein of Galen, petrosal, or straight sinus, extensive cortical venous drainage, and venous varices (51). Weon et al. evaluated 41 patients in the pediatric age group with pial fistula and found the mean age of presentation was 24 months. Out of 41 pediatric patients 7 presented with cerebral hemorrhage (17.1\%) (48).

Prenatal diagnosis of AVFs usually occurs using fetal ultrasonography $(52,53)$. AVFs in the pediatric patient can manifest with high output cardiac failure, non-obstructive hydrocephalus, developmental delay, macrocrania, cognitive impairment, seizures, or focal neurological deficits resulting from large venous varices with mass effect (48, 52-54). Infants with congestive cardiac failure exhibit high-flow fistula demonstrate tachycardia, respiratory distress, poor systemic perfusion, and cyanosis. An audible murmur or cranial might be 
auscultated (55). Venous congestion may lead to non-obstructive hydrocephalus secondary to venous hypertension.

MRI has limitations in the diagnosis of AVFs but can be used to evaluate for cerebral or spinal cord edema, dilated veins related to venous reflux, or ischemic infarct or atrophy. Catheter angiography is the gold standard diagnostic test where the presence of an AV shunting is demonstrated (56-58). Suspicion of an AVF warrants a 5-vessel angiogram to include the examination of the external carotid artery or all spinal radicular vessels. Venous outflow and the presence of stenosis of the venous outflow, arterial feeders, and the severity of arterial "steal" are all evaluated during cerebral angiography.

Treatment should be targeted at high flow symptomatic lesions $(47,48,52,53,59)$. Smaller slower flow dural AVFs lesions with minimal or no symptoms may be followed long term as these may spontaneously close $(51,60,61)$. However, there is some controversy in the treatment of already profoundly impaired infants $(48,62-64)$ may not be warranted for infants with microcephaly, extensive ischemic injury, or multiorgan failure.

Endovascular techniques have become the first line method for treatment of pediatric AVFs $(31,51,59,65)$. Pial AVFs are more frequently treated transarterially whereas dural AVFs via transvenous. The introduction of the Onyx (ethylene vinyl alcohol copolymer) liquid embolic agent in conjunction with detachable coils has increased the therapeutic efficacy of endovascular approaches for AVFs (41, 42, 51, 59, 66). The objective of the treatment is to obliterate the connection between the arterial feeders and the vein, known as a fistula point. AVF treatment has a high rate of lesion obliteration (86\%) and children 2 years of age or older. Good clinical outcome is observed in $72 \%$. However, children $<2$ years of age have increased complication rates and often require more than one more procedure due to the limitations of contrast and radiation $(67,68)$. Venous infarction, migration of embolic agents, guide wire rupture of vessels, post-treatment thrombosis of veins, hyperperfusion syndrome, and hydrocephalus are all complications of AVF treatment $(41,42,51,69)$ with a risk of major complications and death between 5 and 10\% [Figure 2; $(46,68,70)]$.

Microsurgical resection is usually reserved for cases when the risk of embolization of eloquent brain cortex is high (41, 42, 71). Pial AVFs have a higher chance of cure when combined endovascular and open surgical approaches (71\%) are used. However, dural AVFs have a high likelihood of cure with endovascular treatment alone (85\%) $(41,42)$.

\section{SECTION 3: VEIN OF GALEN MALFORMATIONS}

VOGM is a subtype of dural fistula that results from an abnormal regression of midline venous structures the medial prosencephalic vein of Markowski, which is the precursor of the vein of Galen $(72,73)$. Arteriovenous shunts from arteries that connect with the anterior segment of the median prosencephalic vein, which further enlarges under the stress of high flow from the choroidal arteries. Two types of VOGM, choroidal, and mural (73), exist. The choroidal type consists of various feeders including thalamoperforating, pericallosal arteries, and anterior and posterior choroidals in the subarachnoid space in the choroidal fissure and is usually found in neonates with severe symptoms (Figure 3). The mural type fistulas can be single. Although more commonly they are multiple and congregate into a single venous chamber (Figure 4). They usually present with macrocephaly secondary to hydrocephalus. Mixed types can be also seen (74).

Ultrasonography is used to assess VOGM flow in an ill neonate although a large procencephalic vein can be seen during the third trimesters of gestation by ultrasound. MRI of the brain can evaluate the brain for cerebral atrophy or ischemia that may be secondary to a CBF steal phenomenon. Cardiac function is assessed using echocardiography. Echocardiogram may show a dilated superior vena cava, dilated innominate vein, and right ventricular dilatation suggesting evidence of high cardiac preload. Furthermore, there can be diastolic runoff from the patent ductus arteriosus toward the brachiocephalic arteries by color Doppler.

Endovascular treatment is the mainstay treatment for VGOM. Urgent endovascular treatment in the neonatal period is needed when medical management is not successful (74). The goal of treatment is to reduce shunt by $30 \%$ to reverse the PA pressure and reverse abdominal aorta flow, so that heart failure can be managed medically (31). High-output cardiac failure can result in renal or hepatic insufficiency. In older children and infants, treatment is targeted at reducing cognitive delays and cerebral atrophy. It is typically performed in a staged approach. Treatment can be done via a transarterial or transvenous fashion. However, transarterial embolization is the mainstay treatment approach at most centers, reserving transvenous embolization for cases in which transarterial embolization have been completely exhausted $(73,75,76)$. Endovascular embolization results in a good clinical outcome and acceptable mortality and complications. Prior to endovascular intervention, the prognosis of this disease was $100 \%$ mortality without treatment (75).

In situations when hydrocephalus is not reversed postembolization, it is treated with CSF diversion either via shunting or by endoscopic third ventriculostomy. In 2006 Lasjaunias et al. in a series of 233 patients treated with embolization reported the largest VGOM study (76). Mortality was $10.6 \%$. Furthermore, $74 \%$ of those children who survived were neurologically intact, $15.6 \%$ were moderately developmentally delayed, and $10.4 \%$ were severely developmental delayed with a median follow-up of 4.4 years. Obliteration of $90-100 \%$ of the malformation was accomplished in $55 \%$ of patients using an arterial approach with glue embolization. In 2018 systemic review, Brinjikji et al. found that pediatric patients undergoing endovascular embolization of vein of Galen malformations demonstrated good long-term clinical outcomes in $>60 \%$ of cases (77). In this study, the use of the Bicêtre neonatal evaluation score (BNES) resulted in improved rates of good neurologic outcome. One of the key observations from this review was that reports which utilized a predefined the BNES showed higher rates of good neurologic outcome than those that did not (76). The BNES is a 21-point score which assesses 

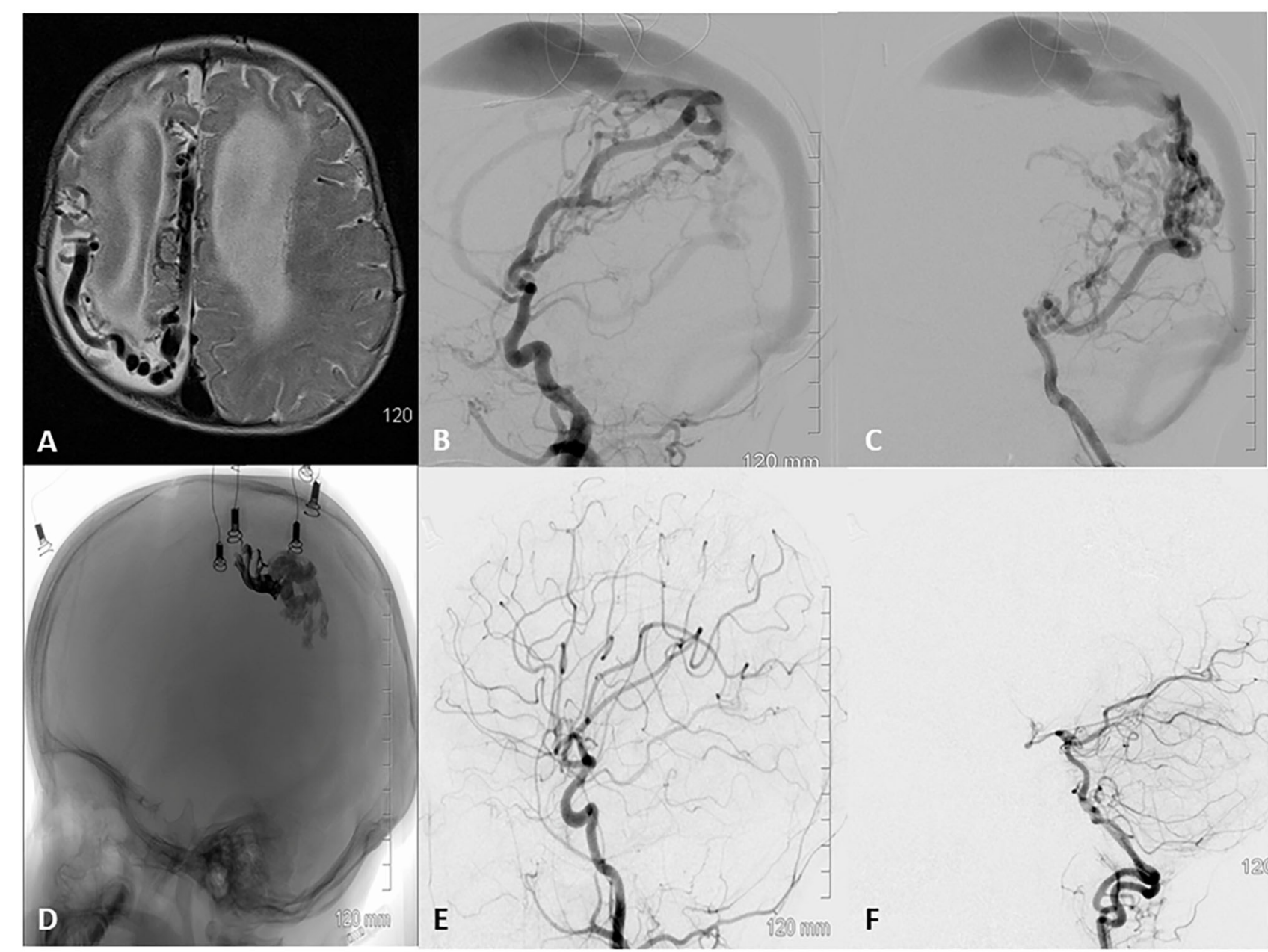

$\mathbf{F}$

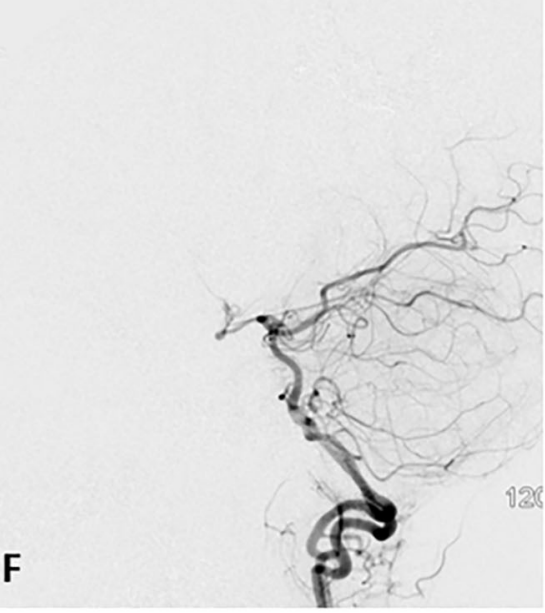

FIGURE 2 | A 36 week old baby was diagnosed with a vascular malformation at 16 weeks of age. The mother noticed abnormal shape of the head with a bulge on the back of right side at 9 weeks and decreased movement of the left hand compared to the right at 16 weeks of age. The right side of the cranial vault is poorly developed, anterior fontanelle is open, full, and pulsating well. (A) MRI revealed numerous enlarged flow void in the midline and right hemisphere, with hydrocephalus and hemiatrophy on the right side of the brain. (B,C) DSA lateral view runs from the right common carotid and left vertebral revealed a pial AVF with arterial feeders arising primarily from the anterior and posterior branches of the right middle cerebral artery and the parieto-occipital branch of the posterior cerebral artery. The fistulas were multi holed and all were drained by a single enlarged venous channel that drained into the superior sagittal sinus. (D) Native lateral skull view demonstrating the final Onyx (darker anterior portion) and NBCA cast sealing several fistulae points over three staging embolization. (E,F) DSA 6 month follow up after last embolization show complete obliteration of the pial AVF with restoration of normal arterial phase.

a combination of cardiac, respiratory, hepatic, renal, and neurologic functions (78).

\section{SECTION 4: ANEURYSMS}

Children compromise $0.5-4.6 \%$ of all unruptured, asymptomatic aneurysms. Ruptured aneurysms are more rare with $0.6 \%$ of all aneurysmal SAH comprising pediatric patients $<19$ years of age (79-81). Children are more likely to present with aneurysms in the posterior circulation ( $25 \%$ children vs. $8 \%$ adults). They are also less likely to have anterior cerebral artery aneurysms (5\% $10 \%$ in children vs. $34 \%$ adults $)(79,80,82-84)$. Children are $2-4$ times more likely to have giant $(>2.5 \mathrm{~cm})$ aneurysms than adults $(79,82,85,86)$.
Aneurysms appearance can be saccular (a focal outpouching of the vessel wall) or fusiform (caused by an injury to the vessel wall usually leading to a dilatation). Mycotic aneurysms are a different type of aneurysm usually caused by infection (rarely tumor) and often appear similar to dissecting aneurysms on angiogram. Younger children ( $<5$ years old) often present with dissecting fusiform aneurysm whereas older children have saccular aneurysms $(79,82,85)$. Most commonly they are saccular and account for $46-70 \%$ of aneurysms. Infectious aneurysms compose $5-15 \%$ of cases and are often are associated with severe cardiac disease and/or systemic infection. Genetic conditions associated with pediatric intracranial aneurysms include fibromuscular dysplasia, Marfan syndrome, polycystic kidney disease, Ehlers-Danlos syndrome, HHT, and KlippelTrenaunay-Weber syndrome (79, 82, 83, 85-89). Table 3 



FIGURE 3 | One-month boy presented with severe high failure requiring pressors and ICU management. Initial ultrasound through the frontal fontanelle showed concerns for a vein of Galen malformation. A vertebral DSA AP (A) and lateral (B) views reveal a high flow vein of Galen choroidal malformation with enlarged choroidal feeders of the posterior cerebral artery, left greater than right. These fistulae drain into a dilated vein of Galen and median vein of the prosencephalon. There is filling of the bilateral transverse sigmoid sinuses, right greater than left as well as some opacification of the occipital.
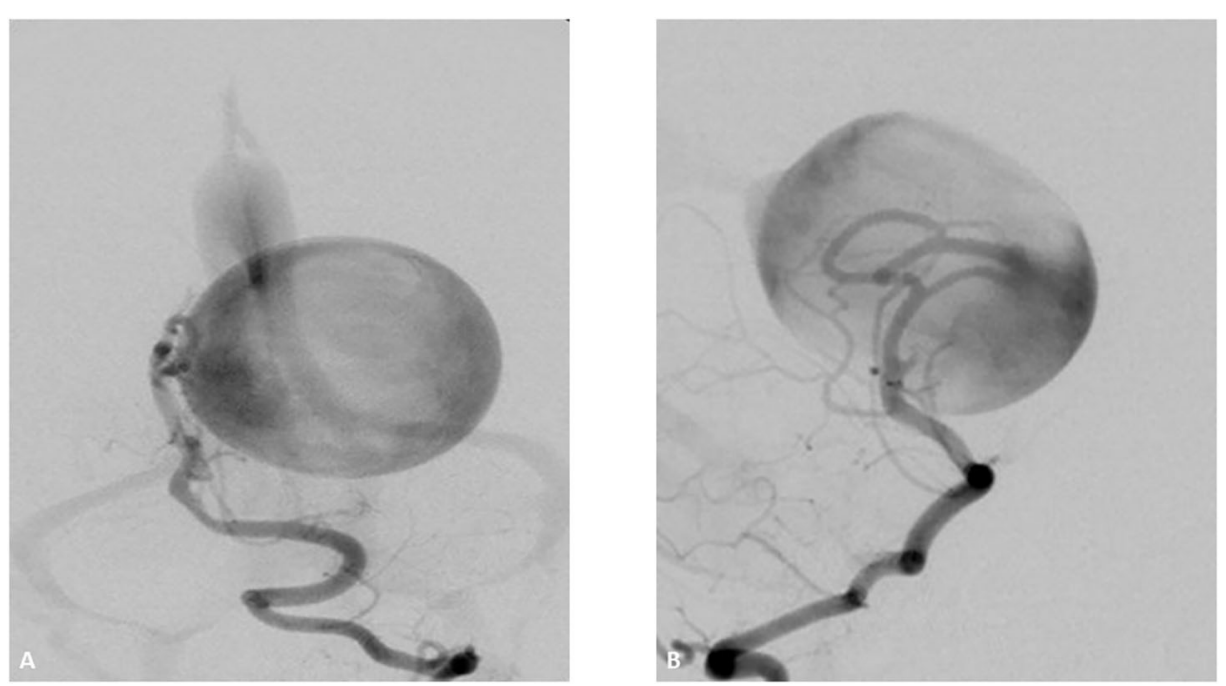

FIGURE 4 | Two-month-old boy presenting with respiratory distress and increase obtundation. Vertebral DSA AP (A) and lateral (B) show a high-flow Mural type Vein of Galen Malformation with feeders arising from the right posterior cerebral artery and draining in to the anterolateral wall of a dilated vein of Galen. There is mild stenosis of the median prosencephalic vein decreasing the venous shunt. The transverse and sigmoid sinuses have normal appearance.

demonstrates heritable disorders associated with an increased incidence of aneurysms in pediatric patients (90-120).

Most aneurysms are asymptomatic and never found. Headache $(80 \%)$ is the most common symptom. This is subsequently followed by loss of consciousness (25\%), seizures (20\%), focal neurological deficits (20\%), and visual changes (10\%) $(79,83,85,87)$. Non-invasive CT/MR angiography followed by DSA are usually performed to establish the diagnosis and best therapeutic approach.

The decision to treat an aneurysm is usually done with collaboration between open surgeons and neurointerventionalists. Endovascular therapy has transformed the treatment of pediatric aneurysms given its non-invasive nature when compared to open surgery. It is critical when possible to have cases reviewed by neurointerventionalists and open surgeons to come up with a balanced treatment strategy. In children lesions $>3 \mathrm{~mm}$ in size usually warrant treatment. Mycotic aneurysms are initially treated with antibiotics and only intervened upon if they are persistent in follow up (Figure 5). Morbidity and mortality of treatment varies with age, aneurysm type, and presentation. Previous series found morbidity rates of $8-14 \%$ and mortality rates of $1-3 \%(87,121)$. Follow-up of the 
aneurysm usually includes angiogram or non-invasive MRA at 6 months and then yearly for 5 years. Other institutions perform imaging every 3-5 years afterwards (122).

TABLE 3 | Heritable disorders associated with intracranial aneurysms.

\begin{tabular}{|c|c|c|}
\hline Disorder & Inheritance & Special features \\
\hline$\alpha$-Glucosidase deficiency & AR & $\begin{array}{l}\text { Aneurysms often } \\
\text { fusiform }\end{array}$ \\
\hline$\alpha_{1}$-Antitrypsin deficiency & AR & $\begin{array}{l}\text { Heterozygotes may be } \\
\text { affected }\end{array}$ \\
\hline Alkaptonuria & AR & \\
\hline Anderson-Fabry disease & XLR & $\begin{array}{l}\text { Aneurysms often } \\
\text { fusiform; Carriers may } \\
\text { be affected }\end{array}$ \\
\hline Autosomal polycystic kidney disease & $A D$ & \\
\hline Ehlers-Danlos syndrome type IV & $A D$ & \\
\hline $\begin{array}{l}\text { Familial idiopathic non-arteriosclerotic } \\
\text { cerebral calcification syndrome }\end{array}$ & $?$ & \\
\hline Hereditary hemorrhagic telangiectasia & $A D$ & \\
\hline Marfan's syndrome & $A D$ & \\
\hline Neurofibromatosis type 1 & $A D$ & \\
\hline Noonan's syndrome & $A D$ & \\
\hline Pseudoxanthoma elasticum & $A D, A R$ & \\
\hline Tuberous sclerosis & $A D$ & $\begin{array}{l}\text { Aneurysms often } \\
\text { fusiform }\end{array}$ \\
\hline $\begin{array}{l}\text { Wermer's syndrome (multiple endocrine } \\
\text { neoplasia type 1) }\end{array}$ & $A D$ & \\
\hline 3M syndrome & $?$ & \\
\hline
\end{tabular}

$A D$, autosomal dominant; $A R$, autosomal recessive; $X L R, X$-linked recessive.

\section{SECTION 5: CAVERNOUS MALFORMATIONS}

Cavernous malformations (CMs) are a type of cerebral vascular malformation (123). They are hamartomatous vascular lesions which macroscopically appear well-circumscribed, multilobulated with reddish purple color. Under the microscope they are seen as packed, enlarged, capillary-like vessels, without intervening parenchyma. Eighty percent of the lesions are supratentorial and the rest are infratentorial. The incidence of CMs in the general population varies from 0.1 to $0.9 \%$ with increased identification with advanced and widespread imaging modalities. CMs may form de novo and be sporadic, though there is higher association of multiple lesions with familial CMs. CMs have preponderance in the Hispanic population. Specifically, in pediatric population, they have been associated with history of radiosurgery for CNS neoplasms. Approximately one-fourth of patients in multiple series were children (124). Seizures are the most common presentation of patients with CMs. They occur in $40-50 \%$ of the patients and are likely due to their cortical location and possible irritation of surrounding parenchyma (124). Initial hemorrhage rate is $0.1-1.4 \%$ in sporadic lesions while $0.7-2.5 \%$ in familial lesions. The rebleeding risk has been reported as low as $0 \%$ in prospective studies and as high as $17 \%$ in retrospective studies. Infratentorial lesions tend to have a higher initial bleeding risk and rebleeding risk. CMs tends to be more aggressive in pediatric population and to have higher rates of growth and hemorrhage, atypical radiological features, and larger dimensions (125). Radiologically they have been classified into 4 types based on their appearance on MR imaging with colloquial description of "popcorn" appearance with a rim of signal loss secondary to hemosiderin [Figure 6; (126)].

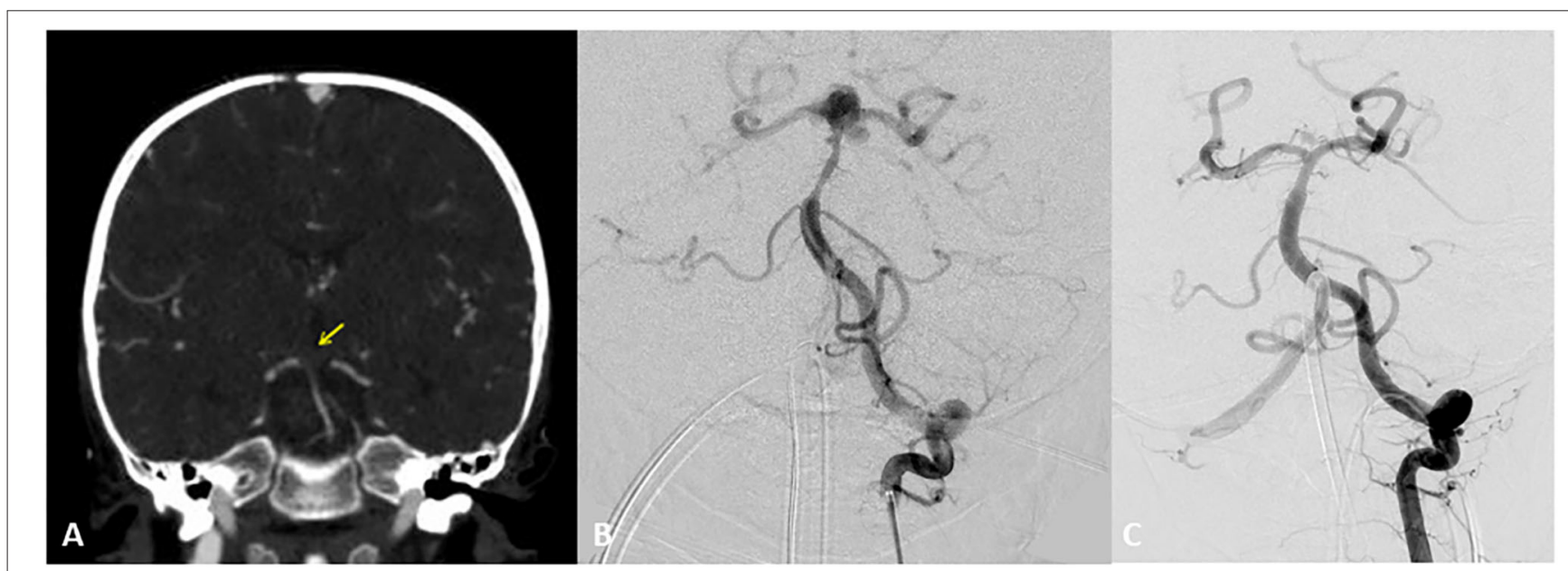

FIGURE 5 | Two-year-old boy with hypoplastic left ventricle status post-cardiac repair presents with fevers, nausea, lethargy, and right sided weakness. Initial CT Angiogram coronal view revealed (A) revealed an acute clot on the top the basilar for which heparin and empiric antibiotics were started. Transthoracic ECHO revealed a large atrial mass and blood cultures revealed Gemella species. Follow up DSA AP view revealed at 2 weeks (B) depicted the development of a bilobular complex basilar tip aneurysm. After careful consideration a flow diverter stent was placed from left posterior cerebral artery to distal basilar artery. At the time of treatment a Pipeline flow diverter was utilized. Currently an alternative option for treatment for this type of wide necked aneurysm would be a WEB (woven endobridge) device. This is a sphere of woven wires appearing like a basket which fills the aneurysm and provides intrasaccular flow diversion. AP DSA view at 6 months (C) follow up revealed near complete resolution of the aneurysm. Patient underwent heart transplantation 2 months later. Yellow arrow indicates acute clot on the top the basilar. 


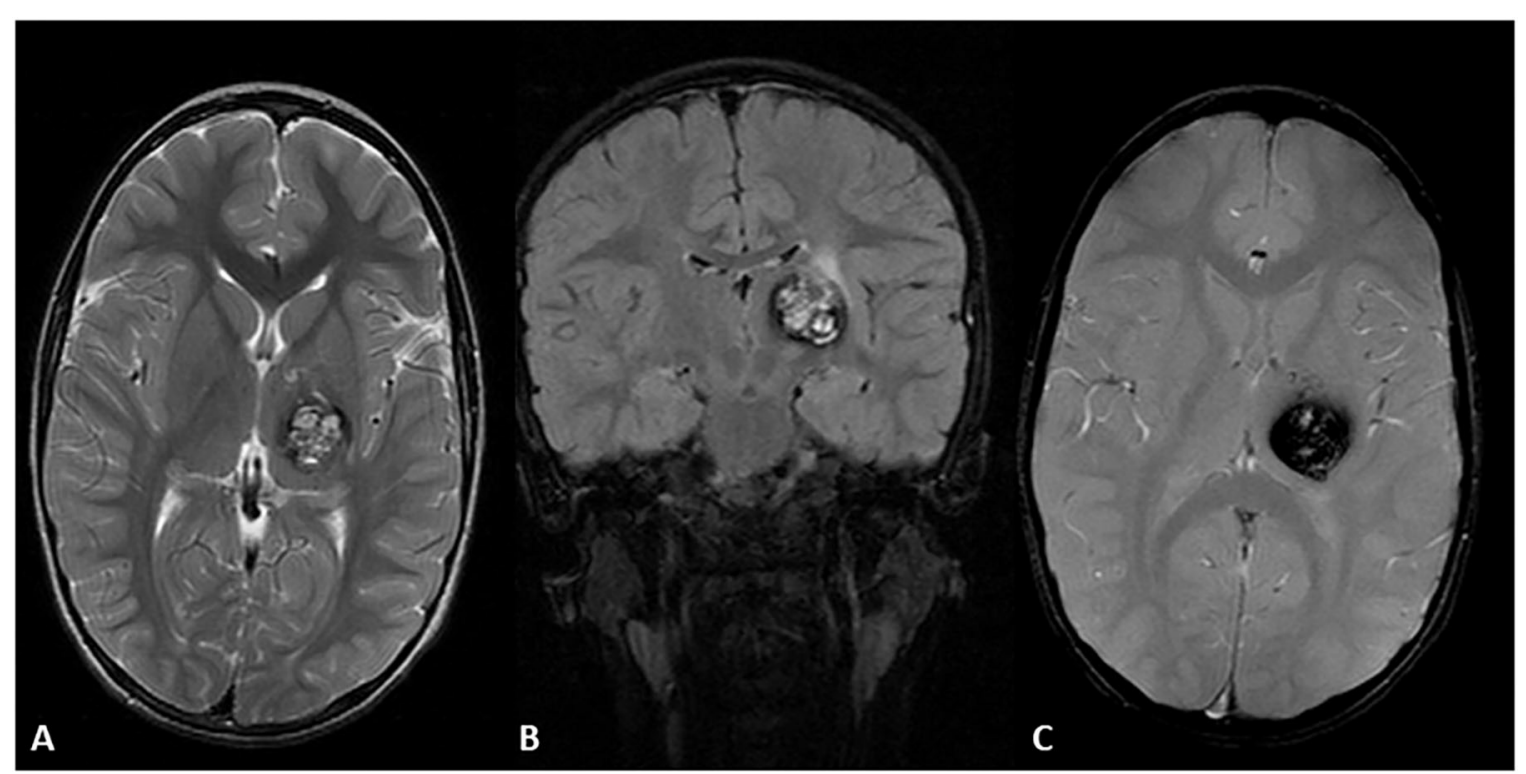

FIGURE 6 | Four-year-old Hispanic girl presented with right sided tremor in the context of a new lesion compatible with cavernous malformation with subacute bleeding of the left thalamus. MRI axial T2 sequence (A) heterogenous hyperintense lesion with a hypointense rim due to subacute internal bleeding know as a "popcorn" appearance. MRI coronal FLAIR (B,C) demonstrates the same lesion with surrounding edema in the upper region of the lesion. MRI axial GRE T2 sequence demonstrates a prominent blooming artifact. T1 post-contrast showed no enhancement (not shown).

CMs are angiographically occult vascular lesions. Conservative management with serial clinical and imaging follow up is the mainstay of treatment for CMs without gross hemorrhage or intractable seizures. It is also the default option for multiple asymptomatic CMs or surgically inaccessible or with high risk of morbidity. Otherwise surgical resection of CMs with or without neurophysiological monitoring has been well-reported in the literature. Surgical outcomes in most post-pediatric case series report $\sim 0 \%$ mortality rate and a $4-5 \%$ rate of new permanent deficits $(127,128)$. Surgical resection of supratentorial lobar lesions yields high rates of symptomatic improvement with $98 \%$ resection rates and obliteration of seizures in $96 \%$ of patients (129). Radiographic follow-up is needed because CMs can recur. This can be seen in radiation-induced and familial cases (130, 131). Several centers order annual MRI studies for the initial 3-5 years after the resection with increasing intervals thereafter $(129,132)$. Radiosurgery of CMs remains controversial due to variable outcomes. Radiation therapy is used for surgically inaccessible targets demonstrating malignant natural history (133). Almost 25\% of all cerebral cavernous malformations are linked with DVAs.

\section{SECTION 6: DEVELOPMENTAL VENOUS ANOMALIES (DVAs)}

The most common vascular malformations of the brain seen on routine imaging are developmental venous anomalies (DVAs). Fortunately, these lesions are often asymptomatic and incidentally found. DVAs are connected with parenchymal abnormalities and specific conditions like cerebral cavernous malformations. DVA angiographic architecture consists of a caput medusa and a medullary stem serving as a collecting vein. DVAs form the primary or only venous drainage for the area of the brain within their drainage territory. The caput medusa venous radicles are histologically defined by thin walled venous channels divided by normal brain parenchyma. The DVA collector is usually compromised of a thicker wall lacking a smooth muscle layer or elastica lamina $(127,128)$. Often, neuronal degeneration, gliosis, ischemic changes, and demyelination are demonstrated within the parenchyma (134136). Based on previous autopsy studies the prevalence of DVAs is $\sim 2.7 \%$ (137). However, recent imaging studies demonstrate the prevalence is higher at $\sim 6.4 \%$ (138). Although the pathogenesis of DVAs is not completely understood, there is thought that to arise from intrauterine life. Some experts believe that DVAs are result from a cessation of normal venous development and a retention of primary medullary veins. Eventually this results in a recruitment of transparenchymal anastomotic drainage routes leading to development of a classic DVA draining into a superficial or normal deep vein. Some studies show that the angioarchitecture of DVAs may evolve during postnatal period and not during prenatal development $(139,140)$.

DVAs are typically asymptomatic. In a prospective cohort of 80 patients, McLaughlin et al. found a $0.68 \% /$ year risk of hemorrhage in DVAs (141). This risk is most likely related to associated cerebral cavernous malformations. Pereira et al. performed a study in adults and children and found following pathomechanisms responsible for symptoms: thrombosis and secondary infarction/hemorrhage (38\%), associated arteriovenous shunting phenomena with or without hemorrhage $(28 \%)$, mass effect from venous drainage causing 
hydrocephalus or cranial nerve injury (20\%), and parenchymal injury/gliosis from increased venous pressure (6\%) (142). DVAs are supratentorial in $70 \%$ or more of the time and infratentorial $14-19 \%$ of the time. The supratentorial areas which are more commonly affected are the frontal lobe (36-56\%), parietal lobe (12-24\%), temporal lobe (2-19\%), and occipital lobe (4\%). In infratentorial DVAs the most commonly affected region is the cerebellum (14-29\%) with minority found in the brainstem $(<5 \%)(143-145)$.

DVAs are usually found on CT and MRI imaging. They are usually not seen on non-contrast CT. However, in large DVAs a tubular focus is visible. This tubular focus can be confused with intracranial hemorrhage given its attenuation is similar to cerebral blood vessels. On contrast-enhanced CT and MRI, the transparenchymal vein is the most distinct feature. In smaller DVAs, an ill-defined contrast blush can be seen related to the venous radicles. On MR imaging, the collecting vein may show up as a flow void on T2 imaging. There is variability in the T2 signal related to the venous radicles. This is dependent on venous flow and acquisition angle. Venous radicles can demonstrate a hyperintense signal on fluid-attenuated inversion recovery (FLAIR) imaging. Susceptibility weighted imaging (SWI) is a sensitive method of detecting DVAs. This is because of the deoxygenated venous blood within the DVA, On SWI, the venous radicles and larger collecting vein are usually hypointense/dark $(146,147)$.

Horsch et al. (140) recently described DVAs in 14 neonates. In this series, DVAs (11/14) demonstrated hyperechoic parenchyma within the drainage territory. However, the reason for this elevated echogenicity remains to be elucidated. Most DVAs showed venous waveforms on doppler. A small proportion (4/14) demonstrated arterial-like waveforms. DVAs that are arterialized are typically rare. Horsch et al. (140) conjectured that this was

\section{REFERENCES}

1. Fullerton HJ, Wu YW, Zhao S, Johnston SC. Risk of stroke in children: ethnic and gender disparities. Neurology. (2003) 61:189-94. doi: 10.1212/01.WNL.0000078894.79866.95

2. Jordan LC, Kleinman JT, Hillis AE. Intracerebral hemorrhage volume predicts poor neurologic outcome in children. Stroke. (2009) 40:166671. doi: 10.1161/STROKEAHA.108.541383

3. Beslow LA, Licht DJ, Smith SE, Storm PB, Heuer GG, Zimmerman RA, et al. Predictors of outcome in childhood intracerebral hemorrhage: a prospective consecutive cohort study. Stroke. (2010) 41:313-8. doi: 10.1161/STROKEAHA.109.568071

4. Adil MM, Qureshi AI, Beslow LA, Malik AA, Jordan LC. Factors associated with increased in-hospital mortality among children with intracerebral hemorrhage. J Child Neurol. (2015) 30:1024-8. doi: 10.1177/0883073814552191

5. Al-Jarallah A, Al-Rifai MT, Riela AR, Roach ES. Nontraumatic brain hemorrhage in children: etiology and presentation. J Child Neurol. (2000) 15:284-9. doi: 10.1177/088307380001500503

6. Broderick J, Talbot GT, Prenger E, Leach A, Brott T. Stroke in children within a major metropolitan area: the surprising importance of intracerebral hemorrhage. J Child Neurol. (1993) 8:250-5. doi: 10.1177/088307389300800308

7. Gaballah M, Storm PB, Rabinowitz D, Ichord RN, Hurst RW, Krishnamurthy $\mathrm{G}$, et al. Intraoperative cerebral angiography in arteriovenous malformation secondary to arterialized DVAs being more common in earlier life and that they might lose arterialization later in life with vascular maturation. Early angiographic opacification is demonstrated an arterialized DVAs. The subtypes of arterialized DVAs have been identified type 1, caput medusae blush during arterial phase with no demonstrable arterial feeders or angiographically evident arteriovenous malformation (AVM) nidus; type 2, caput medusae blush during arterial phase with enlarged arterial feeders but no angiographically evident AVM nidus; type 3, DVAs draining an angiographically demonstrable AVM (148). The natural history of arterialized DVAs is remains to be elucidated. Treatment depends on clinical symptoms, parenchymal changes (edema/hemorrhage), and angioarchitecture (type). Radiotherapy, surgical, and endovascular approaches have been utilized. Typically, preservation of the DVA is attempted as it typically drains normal parenchymal (149).

\section{AUTHOR'S NOTE}

The aim of this review is to provide insight into pediatric hemorrhagic cerebrovascular disease. This article provides a thorough review of the diagnosis and management of pediatric cerebrovascular hemorrhagic pathology. A special emphasis is placed on neuroendovascular treatment options and several clinical vignettes are presented. This is topic is not frequently addressed and discussed among clinicians. Thus, this review will increase knowledge about this pathology and will empower practitioners to care for this unique patient population.

\section{AUTHOR CONTRIBUTIONS}

All authors listed have made a substantial, direct and intellectual contribution to the work, and approved it for publication. resection in children: a single institutional experience. J Neurosurg Pediatr. (2014) 13:222-8. doi: 10.3171/2013.10.PEDS13291

8. Al-Shahi R, Warlow C. A systematic review of the frequency and prognosis of arteriovenous malformations of the brain in adults. Brain. (2001) 124:190026. doi: 10.1093/brain/124.10.1900

9. Millar C, Bissonnette B, Humphreys RP. Cerebral arteriovenous malformations in children. Can J Anaesth. (1994) 41:32131. doi: 10.1007/BF03009913

10. Kiriş $T$, Sencer $A$, Sahinbaş $M$, Sencer $S$, Imer $M$, Izgi N. Surgical results in pediatric Spetzler-Martin grades I-III intracranial arteriovenous malformations. Childs Nerv Syst. (2005) 21:69-74. doi: 10.1007/s00381-004-1025-0

11. Hoh BL, Ogilvy CS, Butler WE, Loeffler JS, Putman CM, Chapman PH. Multimodality treatment of nongalenic arteriovenous malformations in pediatric patients. Neurosurgery. (2000) 47:346-57. doi: 10.1097/00006123-200008000-00015

12. Wilkins RH. Natural history of intracranial vascular malformations: a review. Neurosurgery. (1985) 16:421-30. doi: 10.1227/00006123-19850300 0-00026

13. Kondziolka D, Humphreys RP, Hoffman HJ, Hendrick EB, Drake JM. Arteriovenous malformations of the brain in children: a forty year experience. Can J Neurol Sci. (1992) 19:40-5. doi: 10.1017/S0317167100042517

14. Fullerton HJ, Achrol AS, Johnston SC, McCulloch CE, Higashida RT, Lawton MT, et al. Long-term hemorrhage risk in children versus 
adults with brain arteriovenous malformations. Stroke. (2005) 36:2099104. doi: 10.1161/01.STR.0000181746.77149.2b

15. Thiex R, Mulliken JB, Revencu N, Boon LM, Burrows PE, Cordisco $\mathrm{M}$, et al. A novel association between RASAl mutations and spinal arteriovenous anomalies. AJNR Am J Neuroradiol. (2010) 31:775-9. doi: 10.3174/ajnr.A1907

16. Altschuler EM, Lunsford LD, Coffey RJ, Bissonette DJ, Flickinger JC. Gamma knife radiosurgery for intracranial arteriovenous malformations in childhood and adolescence. Pediatr Neurosci. (1989) 15:53-61. doi: 10.1159/000120443

17. Griffiths PD, Beveridge CJ, Gholkar A. Angiography in non-traumatic brain haematoma. an analysis of 100 cases. Acta Radiol. (1997) 38:797802. doi: $10.1080 / 02841859709172413$

18. Di Rocco C, Tamburrini G, Rollo M. Cerebral arteriovenous malformations in children. Acta Neurochir (Wien). (2000) 142:145-56. doi: 10.1007/s007010050017

19. Hernesniemi JA, Dashti R, Juvela S, Väärt K, Niemelä M, Laakso A. Natural history of brain arteriovenous malformations: a long-term follow-up study of risk of hemorrhage in 238 patients. Neurosurgery. (2008) 63:8239. doi: 10.1227/01.NEU.0000330401.82582.5E

20. Stapf C, Mast H, Sciacca RR, Choi JH, Khaw AV, Connolly ES, et al. Predictors of hemorrhage in patients with untreated brain arteriovenous malformation. Neurology. (2006) 66:13505. doi: 10.1212/01.wnl.0000210524.68507.87

21. Langer DJ, Lasner TM, Hurst RW, Flamm ES, Zager EL, King JT. Hypertension, small size, and deep venous drainage are associated with risk of hemorrhagic presentation of cerebral arteriovenous malformations. Neurosurgery. (1998) 42:481-6. doi: 10.1097/00006123-199803000-00008

22. Arnaout OM, Gross BA, Eddleman CS, Bendok BR, Getch CC, Batjer HH. Posterior fossa arteriovenous malformations. Neurosurg Focus. (2009) 26:E12. doi: 10.3171/2009.2.FOCUS0914

23. Meisel HJ, Mansmann U, Alvarez H, Rodesch G, Brock M, Lasjaunias P. Cerebral arteriovenous malformations and associated aneurysms: analysis of 305 cases from a series of 662 patients. Neurosurgery. (2000) 46:793800. doi: 10.1227/00006123-200004000-00004

24. Stefani MA, Porter PJ, terBrugge KG, Montanera W, Willinsky RA, Wallace MC. Large and deep brain arteriovenous malformations are associated with risk of future hemorrhage. Stroke. (2002) 33:12204. doi: $10.1161 / 01$. STR.0000013738.53113.33

25. Khaw AV, Mohr JP, Sciacca RR, Schumacher HC, Hartmann A, PileSpellman J, et al. Association of infratentorial brain arteriovenous malformations with hemorrhage at initial presentation. Stroke. (2004) 35:660-3. doi: 10.1161/01.STR.0000117093.59726.F9

26. Redekop G, TerBrugge K, Montanera W, Willinsky R. Arterial aneurysms associated with cerebral arteriovenous malformations: classification, incidence, and risk of hemorrhage. J Neurosurg. (1998) 89:539-46. doi: 10.3171/jns.1998.89.4.0539

27. Miyamoto S, Hashimoto N, Nagata I, Nozaki K, Morimoto $\mathrm{M}$, Taki W, et al. Posttreatment sequelae of palliatively treated cerebral arteriovenous malformations. Neurosurgery. (2000) 46:589-94. doi: 10.1097/00006123-200003000-00013

28. Guo WY, Karlsson B, Ericson K, Lindqvist M. Even the smallest remnant of an AVM constitutes a risk of further bleeding. Case report. Acta Neurochir. (1993) 121:212-5. doi: 10.1007/BF01809278

29. Kano H, Kondziolka D, Flickinger JC, Yang H-C, Flannery TJ, Awan NR, et al. Stereotactic radiosurgery for arteriovenous malformations, part 2: management of pediatric patients. J Neurosurg Pediatr. (2012) 9:110. doi: 10.1097/01.CNE.0000411034.97759.08

30. Blount JP, Oakes WJ, Tubbs RS, Humphreys RP. History of surgery for cerebrovascular disease in children. Part III. Arteriovenous malformations. Neurosurg Focus. (2006) 20:E11. doi: 10.3171/foc.2006.20.6.11

31. Berenstein A, Ortiz R, Niimi Y, Elijovich L, Fifi J, Madrid M, et al. Endovascular management of arteriovenous malformations and other intracranial arteriovenous shunts in neonates, infants, and children. Childs Nerv Syst. (2010) 26:1345-58. doi: 10.1007/s00381-010-1206-y

32. Soltanolkotabi M, Schoeneman SE, Alden TD, Hurley MC, Ansari SA, DiPatri AJ, et al. Onyx embolization of intracranial arteriovenous malformations in pediatric patients. J Neurosurg Pediatr. (2013) 11:4317. doi: 10.3171/2013.1.PEDS12286

33. Gross BA, Storey A, Orbach DB, Scott RM, Smith ER. Microsurgical treatment of arteriovenous malformations in pediatric patients: the Boston children's hospital experience. J Neurosurg Pediatr. (2015) 15:717. doi: 10.3171/2014.9.PEDS146

34. Blamek S, Larysz D, Miszczyk L. Stereotactic linac radiosurgery and hypofractionated stereotactic radiotherapy for pediatric arteriovenous malformations of the brain: experiences of a single institution. Childs Nerv Syst. (2013) 29:651-6. doi: 10.1007/s00381-012-1983-6

35. Patibandla MR, Ding D, Xu Z, Sheehan JP. Stereotactic radiosurgery for pediatric high-grade brain arteriovenous malformations: our experience and review of literature. World Neurosurg. (2017) 102:613-22. doi: 10.1016/j.wneu.2017.03.064

36. Yen CP, Monteith SJ, Nguyen JH, Rainey J, Schlesinger DJ, Sheehan JP. Gamma knife surgery for arteriovenous malformations in children. $J$ Neurosurg Pediatr. (2010) 6:426-34. doi: 10.3171/2010.8.PEDS10138

37. Riva D, Pantaleoni C, Devoti M, Lindquist C, Steiner L, Giorgi C. Radiosurgery for cerebral AVMs in children and adolescents: the neurobehavioral outcome. J Neurosurg. (1997) 86:207-10. doi: 10.3171/jns.1997.86.2.0207

38. Aboukaïs R, Vinchon M, Quidet M, Bourgeois P, Leclerc X, Lejeune J$\mathrm{P}$. Reappearance of arteriovenous malformations after complete resection of ruptured arteriovenous malformations: true recurrence or falsenegative early postoperative imaging result? J Neurosurg. (2017) 126:108893. doi: 10.3171/2016.3.JNS152846

39. Morgenstern PF, Hoffman CE, Kocharian G, Singh R, Stieg PE, Souweidane MM. Postoperative imaging for detection of recurrent arteriovenous malformations in children. J Neurosurg Pediatr. (2016) 17:134-40. doi: 10.3171/2015.6.PEDS14708

40. Blauwblomme T, Bourgeois M, Meyer P, Puget S, Di Rocco F, Boddaert $\mathrm{N}$, et al. Long-term outcome of 106 consecutive pediatric ruptured brain arteriovenous malformations after combined treatment. Stroke. (2014) 45:1664-71. doi: 10.1161/STROKEAHA.113.004292

41. Walcott BP, Smith ER, Scott RM, Orbach DB. Dural arteriovenous fistulae in pediatric patients: associated conditions and treatment outcomes. $J$ Neurointerv Surg. (2013) 5:6-9. doi: 10.1136/neurintsurg-2011-010169

42. Walcott BP, Smith ER, Scott RM, Orbach DB. Pial arteriovenous fistulae in pediatric patients: associated syndromes and treatment outcome. $J$ Neurointerv Surg. (2013) 5:10-4. doi: 10.1136/neurintsurg-2011-010168

43. Saliou G, Eyries M, Iacobucci M, Knebel J-F, Waill M-C, Coulet F, et al. Clinical and genetic findings in children with central nervous system arteriovenous fistulas. Ann Neurol. (2017) 82:972-80. doi: 10.1002/ana.25106

44. Herman JM, Spetzler RF, Bederson JB, Kurbat JM, Zabramski JM. Genesis of a dural arteriovenous malformation in a rat model. J Neurosurg. (1995) 83:539-45. doi: 10.3171/jns.1995.83.3.0539

45. Kraus JA, Stüper BK, Nahser HC, Klockgether T, Berlit P. Significantly increased prevalence of factor $\mathrm{V}$ Leiden in patients with dural arteriovenous fistulas. J Neurol. (2000) 247:521-3. doi: 10.1007/s004150070150

46. Hetts SW, Keenan K, Fullerton HJ, Young WL, English JD, Gupta N, et al. Pediatric intracranial nongalenic pial arteriovenous fistulas: clinical features, angioarchitecture, and outcomes. AJNR Am J Neuroradiol. (2012) 33:1710-9. doi: 10.3174/ajnr.A3194

47. Yoshida Y, Weon YC, Sachet M, Mahadevan J, Alvarez H, Rodesch G, et al. Posterior cranial fossa single-hole arteriovenous fistulae in children: 14 consecutive cases. Neuroradiology. (2004) 46:474-81. doi: 10.1007/s00234-004-1176-4

48. Weon YC, Yoshida Y, Sachet M, Mahadevan J, Alvarez H, Rodesch G, et al. Supratentorial cerebral arteriovenous fistulas (AVFs) in children: review of 41 cases with 63 non choroidal single-hole AVFs. Acta Neurochir. (2005) 147:17-31; discussion 31. doi: 10.1007/s00701-004-0341-1

49. Tomlinson FH, Rüfenacht DA, Sundt TM, Nichols DA, Fode NC. Arteriovenous fistulas of the brain and the spinal cord. J Neurosurg. (1993) 79:16-27. doi: 10.3171/jns.1993.79.1.0016

50. Wedderburn CJ, van Beijnum J, Bhattacharya JJ, Counsell CE, Papanastassiou V, Ritchie V, et al. Outcome after interventional or conservative management of unruptured brain arteriovenous 
malformations: a prospective, population-based cohort study. Lancet Neurol. (2008) 7:223-30. doi: 10.1016/S1474-4422(08)70026-7

51. Kim MS, Han DH, Kwon OK, Oh CW, Han MH. Clinical characteristics of dural arteriovenous fistula. J Clin Neurosci. (2002) 9:147-55. doi: 10.1054/jocn.2001.1029

52. Garel C, Azarian M, Lasjaunias P, Luton D. Pial arteriovenous fistulas: dilemmas in prenatal diagnosis, counseling and postnatal treatment. Report of three cases. Ultrasound Obstet Gynecol. (2005) 26:2936. doi: 10.1002/uog.1957

53. Köroglu M, Cil B, Yeşildag A, Baykal B, Cekirge S, Oyar O. Prenatal diagnosis of intracranial pial arteriovenous fistula and endovascular treatment during the neonatal period. Diagn Interv Radiol. (2006) 12:64-7.

54. Viñuela F, Drake CG, Fox AJ, Pelz DM. Giant intracranial varices secondary to high-flow arteriovenous fistulae. J Neurosurg. (1987) 66:198203. doi: $10.3171 /$ jns.1987.66.2.0198

55. Aguilar M, González A, López A, Gutiérrez I, Durand F, Mayol A. Endovascular treatment of a pial arteriovenous fistula with occipital remodeling secondary to giant torcular dilation. J Child Neurol. (2011) 26:1015-20. doi: 10.1177/0883073810397363

56. Panasci DJ, Nelson PK. MR imaging and MR angiography in the diagnosis of dural arteriovenous fistulas. Magn Reson Imaging Clin N Am. (1995) 3:493508 .

57. Shin EJ, Lalwani AK, Dowd CF. Role of angiography in the evaluation of patients with pulsatile tinnitus. Laryngoscope. (2000) 110:191620. doi: 10.1097/00005537-200011000-00028

58. Malek AM, Halbach VV, Dowd CF, Higashida RT. Diagnosis and treatment of dural arteriovenous fistulas. Neuroimaging Clin N Am. (1998) 8:445-68.

59. Newman CB, Hu YC, McDougall CG, Albuquerque FC. Balloon-assisted Onyx embolization of cerebral single-channel pial arteriovenous fistulas. $J$ Neurosurg Pediatr. (2011) 7:637-42. doi: 10.3171/2011.4.PEDS10577

60. Halbach VV, Hieshima GB, Higashida RT, Reicher M. Carotid cavernous fistulae: indications for urgent treatment. AJR Am J Roentgenol. (1987) 149:587-93. doi: 10.2214/ajr.149.3.587

61. Halbach VV, Higashida RT, Hieshima GB, Goto K, Norman D, Newton TH. Dural fistulas involving the transverse and sigmoid sinuses: results of treatment in 28 patients. Radiology. (1987) 163:443-7. doi: 10.1148/radiology.163.2.3562824

62. Rodesch G, Hui F, Alvarez H, Tanaka A, Lasjaunias P. Prognosis of antenatally diagnosed vein of Galen aneurysmal malformations. Childs Nerv Syst. (1994) 10:79-83. doi: 10.1007/BF00302765

63. de Koning TJ, Gooskens R, Veenhoven R, Meijboom EJ, Jansen GH, Lasjaunias P, et al. Arteriovenous malformation of the vein of Galen in three neonates: emphasis on associated early ischaemic brain damage. Eur J Pediatr. (1997) 156:228-9. doi: 10.1007/s004310050589

64. Chevret L, Durand P, Alvarez H, Lambert V, Caeymax L, Rodesch G, et al. Severe cardiac failure in newborns with VGAM. Prognosis significance of hemodynamic parameters in neonates presenting with severe heart failure owing to vein of Galen arteriovenous malformation. Intensive Care Med. (2002) 28:1126-30. doi: 10.1007/s00134-002-1381-8

65. Natarajan SK, Ghodke B, Kim LJ, Hallam DK, Britz GW, Sekhar LN. Multimodality treatment of intracranial dural arteriovenous fistulas in the Onyx era: a single center experience. World Neurosurg. (2010) 73:36579. doi: 10.1016/j.wneu.2010.01.009

66. Thiex R, Williams A, Smith E, Scott RM, Orbach DB. The use of Onyx for embolization of central nervous system arteriovenous lesions in pediatric patients. AJNR Am J Neuroradiol. (2010) 31:112-20. doi: 10.3174/ajnr.A1786

67. Pasquale EB, Deerinck TJ, Singer SJ, Ellisman MH. Cek5, a membrane receptor-type tyrosine kinase, is in neurons of the embryonic and postnatal avian brain. J Neurosci. (1992) 12:3956-67. doi: 10.1523/JNEUROSCI.12-10-03956.1992

68. Kraneburg UM, Nga VDW, Ting EYS, Hui FKH, Lwin S, Teo C, et al. Intracranial pial arteriovenous fistula in infancy: a case report and literature review. Childs Nerv Syst. (2014) 30:365-9. doi: 10.1007/s00381-013-2217-2

69. Halbach VV, Higashida RT, Hieshima GB, Norman D. Normal perfusion pressure breakthrough occurring during treatment of carotid and vertebral fistulas. AJNR Am J Neuroradiol. (1987) 8:751-6.

70. Lownie SP. Intracranial dural arteriovenous fistulas: endovascular therapy. Neurosurg Clin N Am. (1994) 5:449-58. doi: 10.1016/S1042-3680(18)30512-6
71. Passacantilli E, Pichierri A, Guidetti G, Santoro A, Delfini R. Surgical treatment of pial cerebellar arteriovenous fistulas with aneurysm of the main feeding artery. Surg Neurol. (2006) 65:90-4. doi: 10.1016/j.surneu.2005.04.005

72. Raybaud CA, Strother CM. Persisting abnormal embryonic vessels in intracranial arteriovenous malformations. Acta Radiol Suppl. (1986) 369:136-8.

73. Gailloud P, O'Riordan DP, Burger I, Levrier O, Jallo G, Tamargo RJ, et al. Diagnosis and management of vein of galen aneurysmal malformations. $J$ Perinatol. (2005) 25:542-51. doi: 10.1038/sj.jp.7211349

74. Chow ML, Cooke DL, Fullerton HJ, Amans MR, Narvid J, Dowd CF, et al. Radiological and clinical features of vein of Galen malformations. $J$ Neurointerv Surg. (2015) 7:443-8. doi: 10.1136/neurintsurg-2013-011005

75. Berenstein A, Fifi JT, Niimi Y, Presti S, Ortiz R, Ghatan S, et al. Vein of Galen malformations in neonates: new management paradigms for improving outcomes. Neurosurgery. (2012) 70:1207-13. doi: 10.1227/NEU.0b013e3182417be3

76. Lasjaunias PL, Chng SM, Sachet M, Alvarez H, Rodesch G, Garcia-Monaco R. The management of vein of Galen aneurysmal malformations. Neurosurgery. (2006) 59:S18494. doi: 10.1227/01.NEU.0000237445.39514.16

77. Brinjikji W, Krings T, Murad MH, Rouchaud A, Meila D. Endovascular treatment of vein of galen malformations: a systematic review and meta-analysis. AJNR Am J Neuroradiol. (2017) 38:2308-14. doi: 10.3174/ajnr.A5403

78. Alvarez H, Garcia Monaco R, Rodesch G, Sachet M, Krings T, Lasjaunias P. Vein of galen aneurysmal malformations. Neuroimaging Clin N Am. (2007) 17:189-206. doi: 10.1016/j.nic.2007.02.005

79. Gemmete JJ, Toma AK, Davagnanam I, Robertson F, Brew S. Pediatric cerebral aneurysms. Neuroimaging Clin N Am. (2013) 23:771-9. doi: 10.1016/j.nic.2013.03.018

80. Locksley HB, Sahs AL, Knowler L. Report on the cooperative study of intracranial aneurysms and subarachnoid hemorrhage. Section II. General survey of cases in the central registry and characteristics of the sample population. J Neurosurg. (1966) 24:922-32. doi: 10.3171/jns.1966.24.5.0922

81. Roche JL, Choux M, Czorny A, Dhellemmes P, Fast M, Frerebeau P, et al. [Intracranial arterial aneurysm in children. a cooperative study. apropos of 43 cases]. Neurochirurgie. (1988) 34:243-51.

82. Allison JW, Davis PC, Sato Y, James CA, Haque SS, Angtuaco EJ, et al. Intracranial aneurysms in infants and children. Pediatr Radiol. (1998) 28:223-9. doi: $10.1007 / \mathrm{s} 002470050336$

83. Lasjaunias P, Wuppalapati S, Alvarez H, Rodesch G, Ozanne A. Intracranial aneurysms in children aged under 15 years: review of 59 consecutive children with 75 aneurysms. Childs Nerv Syst. (2005) 21:43750. doi: 10.1007/s00381-004-1125-x

84. International Study of Unruptured Intracranial Aneurysms Investigators. Unruptured intracranial aneurysms-risk of rupture and risks of surgical intervention. N Engl J Med. (1998) 339:1725-33. doi: 10.1056/NEJM199812103392401

85. Garg K, Singh PK, Sharma BS, Chandra PS, Suri A, Singh M, et al. Pediatric intracranial aneurysms-our experience and review of literature. Childs Nerv Syst. (2014) 30:873-83. doi: 10.1007/s00381-013-2336-9

86. Gerosa M, Licata C, Fiore DL, Iraci G. Intracranial aneurysms of childhood. Childs Brain. (1980) 6:295-302. doi: 10.1159/000119917

87. Hetts SW, Narvid J, Sanai N, Lawton MT, Gupta N, Fullerton HJ, et al. Intracranial aneurysms in childhood: 27-year single-institution experience. AJNR Am J Neuroradiol. (2009) 30:1315-24. doi: 10.3174/ajnr.A1587

88. Perez JL, McDowell MM, Zussman B, Jadhav AP, Miyashita Y, McKiernan $\mathrm{P}$, et al. Ruptured intracranial aneurysm in a patient with autosomal recessive polycystic kidney disease. J Neurosurg Pediatr. (2018) 23:759. doi: 10.3171/2018.8.PEDS18286

89. Dunn IF, Woodworth GF, Siddiqui AH, Smith ER, Vates GE, Day AL, et al. Traumatic pericallosal artery aneurysm: a rare complication of transcallosal surgery. Case report. J Neurosurg. (2007) 106:1537. doi: 10.3171/ped.2007.106.2.153

90. Miyamoto Y, Etoh Y, Joh R, Noda K, Ohya I, Morimatsu M. Adultonset acid maltase deficiency in siblings. Acta Pathol JPN. (1985) 35:153342. doi: 10.1111/j.1440-1827.1985.tb01450.x 
91. Makos MM, McComb RD, Hart MN, Bennett DR. Alpha-glucosidase deficiency and basilar artery aneurysm: report of a sibship. Ann Neurol. (1987) 22:629-33. doi: 10.1002/ana.410220512

92. Schievink WI, Prakash UB, Piepgras DG, Mokri B. Alpha 1-antitrypsin deficiency in intracranial aneurysms and cervical artery dissection. Lancet. (1994) 343:452-3. doi: 10.1016/S0140-6736(94)92693-X

93. Kaufmann AM, Reddy KK, West M, Halliday WJ. Alkaptonuric ochronosis and multiple intracranial aneurysms. Surg Neurol. (1990) 33:213-6. doi: 10.1016/0090-3019(90)90187-T

94. Maisey DN, Cosh JA. Basilar artery aneurysm and Anderson-Fabry disease. J Neurol Neurosurg Psychiatry. (1980) 43:85-7. doi: 10.1136/jnnp.43.1.85

95. Mitsias P, Levine SR. Cerebrovascular complications of Fabry's disease. Ann Neurol. (1996) 40:8-17. doi: 10.1002/ana.410400105

96. Saifuddin A, Dathan JR. Adult polycystic kidney disease and intracranial aneurysms. $\mathrm{Br} \mathrm{Med} J$ (Clin Res Ed). (1987) 295:526. doi: 10.1136/bmj.295.6597.526

97. Chauveau D, Sirieix ME, Schillinger F, Legendre C, Grünfeld JP. Recurrent rupture of intracranial aneurysms in autosomal dominant polycystic kidney disease. BMJ. (1990) 301:966-7. doi: 10.1136/bmj.301.6758.966

98. Fehlings MG, Gentili F. The association between polycystic kidney disease and cerebral aneurysms. Can J Neurol Sci. (1991) 18:5059. doi: 10.1017/S0317167100032248

99. Chapman AB, Rubinstein D, Hughes R, Stears JC, Earnest $\mathrm{MP}$, Johnson AM, et al. Intracranial aneurysms in autosomal dominant polycystic kidney disease. $N$ Engl J Med. (1992) 327:916-20. doi: 10.1056/NEJM199209243271303

100. Schievink WI, Torres VE, Piepgras DG, Wiebers DO. Saccular intracranial aneurysms in autosomal dominant polycystic kidney disease. J Am Soc Nephrol. (1992) 3:88-95.

101. Kahn E, Markowitz J, Duffy L, Kenigsberg K, Davis JG, Daum F. Berry aneurysms, cirrhosis, pulmonary emphysema, and bilateral symmetrical cerebral calcifications: a new syndrome. Am J Med Genet Suppl. (1987) 3:343-56. doi: 10.1002/ajmg.1320280540

102. Green LN. Progeria with carotid artery aneurysms: report of a case. Arch Neurol. (1981) 38:659-61. doi: 10.1001/archneur.1981.00510100087017

103. McAnena O, Padilla JR, Buckley TF. Intracranial aneurysm in association with Noonan's syndrome. Ir Med J. (1984) 77:140-1. doi: 10.1177/014107688407700216

104. Davidson S. Tuberous sclerosis with fusiform aneurysms of both internal carotid arteries manifested by unilateral visual loss and papilledema. Bull Los Angeles Neurol Soc. (1974) 39:128-32.

105. Snowdon JA. Cerebral aneurysm, renal cysts and hamartomas in a case of tuberous sclerosis. $\mathrm{Br} J$ Urol. (1974) 46:583. doi: 10.1111/j.1464-410X.1974.tb03860.x

106. Ho KL. Intraventricular aneurysm associated with tuberous sclerosis. Arch Neurol. (1980) 37:385-6. doi: 10.1001/archneur.1980.00500550087017

107. Beall S, Delaney P. Tuberous sclerosis with intracranial aneurysm. Arch Neurol. (1983) 40:826-7. doi: 10.1001/archneur.1983.04050120076015

108. Blumenkopf B, Huggins MJ. Tuberous sclerosis and multiple intracranial aneurysms: case report. Neurosurgery. (1985) 17:797-800. doi: 10.1097/00006123-198511000-00012

109. Brill CB, Peyster RG, Hoover ED, Keller MS. Giant intracranial aneurysm in a child with tuberous sclerosis: CT demonstration. J Comput Assist Tomogr. (1985) 9:377-80. doi: 10.1097/00004728-198503000-00031

110. Copley DJ. Case of the season. Diagnosis: intracranial aneurysms in a patient with tuberous sclerosis. Semin Roentgenol. (1985) 20:1079. doi: 10.1016/0037-198X(85)90060-4

111. Mueller RF, Buckler J, Arthur R, Bonsor G, Dear P, Walters K, et al. The 3-M syndrome: risk of intracerebral aneurysm? J Med Genet. (1992) 29:425-7. doi: 10.1136/jmg.29.6.425

112. Schievink WI, Michels VV, Piepgras DG. Neurovascular manifestations of heritable connective tissue disorders. A review. Stroke. (1994) 25:889903. doi: 10.1161/01.STR.25.4.889

113. Czernobilsky B, Bouzarth WF. Vascular malformations in the brain in a patient with multiple telangiectasia of the intestine and lungs. J Am Med Womens Assoc. (1965) 20:337-40.

114. Grollmus J, Hoff J. Multiple aneurysms associated with Osler-Weber-Rendu disease. Surg Neurol. (1973) 1:91-3.
115. Román G, Fisher M, Perl DP, Poser CM. Neurological manifestations of hereditary hemorrhagic telangiectasia (Rendu-Osler-Weber disease): report of 2 cases and review of the literature. Ann Neurol. (1978) 4:13044. doi: 10.1002/ana.410040207

116. Kamiyama K, Okada H, Niizuma H, Higuchi H. [A case report: Osler-WeberRendu disease with cerebral aneurysm, cerebral arteriovenous malformation and pulmonary arteriovenous fistula (author's transl)]. No Shinkei Geka. (1981) 9:67-72.

117. Roy C, Noseda G, Arzimanoglou A, Harpey JP, Binet MH, Vaur C, et al. [Rendu Osler disease revealed by ruptured cerebral arterial aneurysm in an infant]. Arch Fr Pediatr. (1990) 47:741-2.

118. ter Berg JW, Dippel DW, Habbema JD, Westermann CJ, Tulleken CA, Willemse J. Unruptured intracranial arteriovenous malformations with hereditary haemorrhagic telangiectasia. Neurosurgical treatment or not? Acta Neurochir. (1993) 121:34-42. doi: 10.1007/BF01405180

119. Guttman M, Tanen SM, Lambert CD. Visual loss secondary to a giant aneurysm in a patient with tuberous sclerosis. Can J Neurol Sci. (1984) 11:472-4. doi: 10.1017/S0317167100046035

120. Adachi K, Kudo M, Chen MN, Nakazawa S, Wakabayashi I. Cerebral aneurysm associated with multiple endocrine neoplasia, type 1-case report. Neurol Med Chir. (1993) 33:309-11. doi: 10.2176/nmc.33.309

121. Kakarla UK, Beres EJ, Ponce FA, Chang SW, Deshmukh VR, Bambakidis NC, et al. Microsurgical treatment of pediatric intracranial aneurysms: longterm angiographic and clinical outcomes. Neurosurgery. (2010) 67:23749. doi: 10.1227/01.NEU.0000371727.71991.64

122. Tonn J, Hoffmann O, Hofmann E, Schlake HP, Sörensen N, Roosen K. “De novo" formation of intracranial aneurysms: who is at risk? Neuroradiology. (1999) 41:674-9. doi: 10.1007/s002340050823

123. McCormick WF, Hardman JM, Boulter TR. Vascular malformations ("angiomas") of the brain, with special reference to those occurring in the posterior fossa. J Neurosurg. (1968) 28:24151. doi: 10.3171/jns.1968.28.3.0241

124. Maraire JN, Awad IA. Intracranial cavernous malformations: lesion behavior and management strategies. Neurosurgery. (1995) 37:591-605. doi: 10.1097/00006123-199510000-00001

125. Acciarri N, Galassi E, Giulioni M, Pozzati E, Grasso V, Palandri G, et al. Cavernous malformations of the central nervous system in the pediatric age group. Pediatr Neurosurg. (2009) 45:81-104. doi: 10.1159/000209283

126. Zabramski JM, Wascher TM, Spetzler RF, Johnson B, Golfinos J, Drayer BP, et al. The natural history of familial cavernous malformations: results of an ongoing study. J Neurosurg. (1994) 80:422-32. doi: 10.3171/jns.1994.80.3.0422

127. Scott RM, Barnes P, Kupsky W, Adelman LS. Cavernous angiomas of the central nervous system in children. J Neurosurg. (1992) 76:3846. doi: 10.3171/jns.1992.76.1.0038

128. Amin-Hanjani S, Ogilvy CS, Ojemann RG, Crowell RM. Risks of surgical management for cavernous malformations of the nervous system. Neurosurgery. (1998) 42:1220-7. doi: 10.1097/00006123-19980600000007

129. Gross BA, Smith ER, Goumnerova L, Proctor MR, Madsen JR, Scott RM. Resection of supratentorial lobar cavernous malformations in children: clinical article. J Neurosurg Pediatr. (2013) 12:367-73. doi: 10.3171/2013.7.PEDS13126

130. Baumgartner JE, Ater JL, Ha CS, Kuttesch JF, Leeds NE, Fuller GN, et al. Pathologically proven cavernous angiomas of the brain following radiation therapy for pediatric brain tumors. Pediatr Neurosurg. (2003) 39:2017. doi: 10.1159/000072472

131. Larson JJ, Ball WS, Bove KE, Crone KR, Tew JM. Formation of intracerebral cavernous malformations after radiation treatment for central nervous system neoplasia in children. J Neurosurg. (1998) 88:516. doi: 10.3171/jns.1998.88.1.0051

132. Frim DM, Scott RM. Management of cavernous malformations in the pediatric population. Neurosurg Clin N Am. (1999) 10:513-8. doi: 10.1016/S1042-3680(18)30182-7

133. Scott RM. Brain stem cavernous angiomas in children. Pediatr Neurosurg. (1990) 16:281-6. doi: 10.1159/000120543

134. Noran HH. Intracranial vascular tumors and malformations. Arch Pathol. (1945) 39:393-416 
135. Jung G, Schröder R, Lanfermann H, Jacobs A, Szelies B, Schröder R. Evidence of acute demyelination around a developmental venous anomaly: magnetic resonance imaging findings. Invest Radiol. (1997) 32:5757. doi: 10.1097/00004424-199709000-00010

136. Vaitkevicius H, Erdemli HE, Anderson WS, Zamani AA, Friedlander RM, Folkerth RD. Biopsy neuropathology of cerebral ischemia associated with a developmental venous anomaly. Clin Neurol Neurosurg. (2013) 115:6213. doi: 10.1016/j.clineuro.2012.06.014

137. Sarwar M, McCormick WF. Intracerebral venous angioma. Case report and review. Arch Neurol. (1978) 35:3235. doi: 10.1001/archneur.1978.00500290069012

138. Gökçe E, Acu B, Beyhan M, Celikyay F, Celikyay R. Magnetic resonance imaging findings of developmental venous anomalies. Clin Neuroradiol. (2014) 24:135-43. doi: 10.1007/s00062-013-0235-9

139. Leach JL, Howard T, Abruzzo T, Jones BV, Crone K. Postnatal evolution of a developmental venous anomaly. J Pediatr Neuroradiol. (2015) 01:30511. doi: 10.3233/PNR-2012-039

140. Horsch S, Govaert P, Cowan FM, Benders MJNL, Groenendaal F, Lequin MH, et al. Developmental venous anomaly in the newborn brain. Neuroradiology. (2014) 56:579-88. doi: 10.1007/s00234-014-1367-6

141. McLaughlin MR, Kondziolka D, Flickinger JC, Lunsford S, Lunsford LD. The prospective natural history of cerebral venous malformations. Neurosurgery. (1998) 43:195-200. doi: 10.1097/00006123-199808000-00001

142. Pereira VM, Geibprasert S, Krings T, Aurboonyawat T, Ozanne A, Toulgoat F, et al. Pathomechanisms of symptomatic developmental venous anomalies. Stroke. (2008) 39:3201-15. doi: 10.1161/STROKEAHA.108.521799

143. San Millán Ruíz D, Delavelle J, Yilmaz H, Gailloud P, Piovan E, Bertramello A, et al. Parenchymal abnormalities associated with developmental venous anomalies. Neuroradiology. (2007) 49:987-95. doi: 10.1007/s00234-007-0279-0
144. Lee C, Pennington MA, Kenney CM. MR evaluation of developmental venous anomalies: medullary venous anatomy of venous angiomas. AJNR Am J Neuroradiol. (1996) 17:61-70.

145. Valavanis A, Wellauer J, Yaşargil MG. The radiological diagnosis of cerebral venous angioma: cerebral angiography and computed tomography. Neuroradiology. (1983) 24:193-9. doi: 10.1007/BF00399770

146. Sehgal V, Delproposto Z, Haacke EM, Tong KA, Wycliffe N, Kido DK, et al. Clinical applications of neuroimaging with susceptibility-weighted imaging. J Magn Reson Imaging. (2005) 22:439-50. doi: 10.1002/jmr i. 20404

147. Reichenbach JR, Haacke EM. High-resolution BOLD venographic imaging: a window into brain function. NMR Biomed. (2001) 14:453-67. doi: 10.1002/nbm.722

148. Ruíz DSM, Yilmaz H, Gailloud P. Cerebral developmental venous anomalies: current concepts. Ann Neurol. (2009) 66:271-83. doi: 10.1002/ana.21754

149. Bassetti C, Bogousslavsky J, Barth A, Regli F. Isolated infarcts of the pons. Neurology. (1996) 46:165-75. doi: 10.1212/WN L. 46.1 .165

Conflict of Interest: The authors declare that the research was conducted in the absence of any commercial or financial relationships that could be construed as a potential conflict of interest.

Copyright (C) 2020 Guerrero, Dandapat and Ortega-Gutierrez. This is an open-access article distributed under the terms of the Creative Commons Attribution License (CC $B Y)$. The use, distribution or reproduction in other forums is permitted, provided the original author(s) and the copyright owner(s) are credited and that the original publication in this journal is cited, in accordance with accepted academic practice. No use, distribution or reproduction is permitted which does not comply with these terms. 